\title{
FEDERAL OLD-AGE INSURANCE: BENEFIT PAYMENTS AND TAX COLLECTION
}

\author{
David F. Cavers*
}

Title II, "Federal Old-Age Benefits," and Title VIII, "Taxes with Respect to Employment," of the Social Security Act form, if combined, what is somewhat inaccurately known as the Federal Old-Age Insurance System. The development of this legislation and the salient problems it presents are dealt with in other articles in this symposium. The purpose of this article is merely to sketch the mechanism which these titles have created and, without venturing too far into the realm of prophecy, to suggest some of the administrative problems which may be encountered in its operation.

Before an examination of the separate parts of the system is undertaken, a rough sketch of the whole may be useful. Title II establishes an Old-Age Reserve Account ${ }^{1}$ in the Treasury to which appropriations are to be made annually in amounts, determined actuarially on a reserve basis at a 3 per cent interest rate, sufficient to meet the benefit payments required under the succeeding sections of the title. These benefit payments are to be made in monthly instalments to persons having attained age 65 who are no longer employed. Payments continue until the death of the recipient. They are based on the total wages received since 1936 by employees engaged in employments other than seven specifically excepted by the Act. Provision is made for death benefits payable to employees dying before having attained age 65 . Benefits are payable regardless of the need of the recipient; millionaire and pauper alike may qualify.

Title VIII levies taxes on wages received by employees and paid by employers. The proceeds of these taxes are payable into the general funds of the Treasury and are not earmarked for benefit payments. However, as will be seen, the tax base is the same as the base for benefit payments, and the taxes were fixed with reference to the revenue requirements of the benefit system.

The benefit provisions are to be administered by the Social Security Board; the fiscal and revenue provisions, by the Treasury Department.

- B.S. in Econ., I923, University of Pennsylvania; LI.B., 1926, Harvard University. Member of the New York Bar. Professor of Law, Duke University School of Law. Editor, Law AND Contenaporary Proslener. Contributor to legal periodicals.

1 The determination of the amount of the annual appropriation and the set-up and administration of the Old-Age Reserve Account will not be discussed in this article. For the consideration of this topic, see Modlin, The Old-Age Reserve Account and its Economic Implications, infra, p. 221. 
From a legal standpoint, the old-age insurance provisions are relatively simple. The administrative difficulties which may be envisaged flow chiefly from the tremendous magnitude of the undertaking, although, as will be seen, the separation of the benefit provisions in Title II from the taxing provisions in Title VIII complicates the administrative task materially. This separation, as has been explained in Dr. Brown's paper, 2 was dictated by constitutional considerations. The separation is more than formal, but any effort to depict the system as a going concern must begin by breaking it down.

\section{The Coverage of THe System}

Title II, in defining those "qualified individuals" who are entitled to receive benefit payments, specifies persons who have engaged in "employment" on some five days after December 3r, 1936, and before attaining the age of 65, each day being in a different calendar year. "Employment" in turn is subjected to definition, meaning "any service, of whatever nature, performed within the United States by an employee for his employer, except ..." and there follows a list of excepted employments, to be set forth shortly.

Turning to Title VIII one finds an income tax on employers with respect to wages received in "employment" and an excise tax on every employer "with respect to having individuals in his employ" in "employment." When one comes to examine the definition of "employment" as used in these two sections one finds it almost identical ${ }^{72}$ to that employed in Title II to determine those entitled to receive benefit paymients.

Still another link exists between the two titles. The benefit payments provided by Title II are to be calculated with reference to the total "wages" received by qualified individuals after December $3{ }^{1}, 1936^{8}{ }^{8}$ and the term "wages" is defined in a subsequent section of that title. ${ }^{9}$ Now the two taxes imposed by Title VIII are expressed in terms of a percentage of the "wages" received and paid, respectively, by employees and employers subject to the taxes, ${ }^{10}$ and the definition of "wages" in this title ${ }^{11}$ is identical to that in Title II.

Combining the two titles, it appears, therefore, that benefits are payable only to those individuals who have contributed to the maintenance of the system by the payment of a tax upon their wages and that consequently the coverage of the benefit and taxing provisions is coterminous. And since the graduated scale of benefit payments is based, in substance if not in form, upon the amount of taxes paid by the ben-

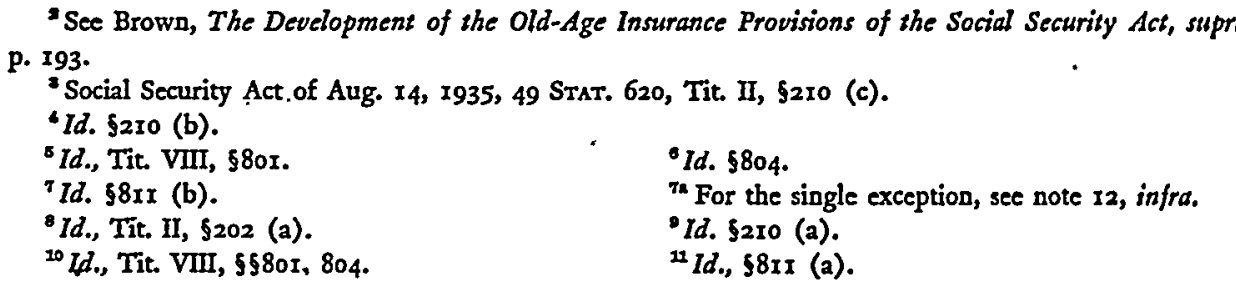


eficiaries, the resemblance to a contractual system of insurance is real-although the creation of contractual obligations is carefully avoided.

The occupations which are excepted by both titles from the operation of the system are the following:12

"(I) Agricultural labor;

"(2) Domestic service in a private home;

“(3) Casual labor not in the course of the employer's trade or business;

"(4) Service performed as an officer or member of the crew of any vessel documented under the laws of the United States or of any foreign country;

"(5) Service performed in the employ of the United States Government or of an instrumentality of the United States;

"(6) Service performed in the employ of. a State, a political subdivision thereof, or an instrumentality of one or more States or political subdivisions;

"(7) Service performed in the employ of a corporation, community chest, fund, or foundation, organized and operated exclusively for religious, charitable, scientific, literary, or educational purposes, or for the prevention of cruelty to children or animals, no part of the net earnings of which inures to the benefit of any private shareholder or individual."

Obviously each of these will present administrative problems of definition, some of which have already been faced by the Bureau of Internal Revenue in drafting the regulations ${ }^{13}$ promulgated under Title IX of the Act, levying an excise tax on employers of eight or more for the purposes of the federal-state unemployment compensation system. Five of the excepted occupations under Titles II and VIII are also excepted under Title IX and a sixth is substantially so. ${ }^{14}$

Title IX makes no attempt to place upon persons engaging independent contractors any accountability for the tax liability of those contractors or of their employees, nor does it render holding companies accountable for their subsidiaries. Perplexing problems as to the definition of the employing unit confronting draftsmen of state unemployment compensation acts are thereby avoided.15 Of course, the problem of determining whether the status of a given individual is that of employee will remain.

The national character of the system also obviates the problems of interstate territorial coverage which arise under the state unemployment compensation acts. ${ }^{16}$ The Act ${ }^{17}$ boldly covers all service performed within the United States, regardless of the transitory character of that service here, the employer's place of business, or the place of contracting or of payment. It is difficult to escape the suspicion that the

Id., Tit. II, \$210 (b), Tit. VIII, \$8II (b). The latter section, cl. (4), also excepts "service performed by an individual who has attained the age of sixty-five" from employment subject to tax.

${ }^{28}$ See U. S. Treas. Reg. 90, art. 206 (1)-206 (3), 206 (5)-206 (7).

Is The occupations numbered ( 1 ), (2), (5), (6), and (7) above are excepted by $\$ 907$ (c) from the tax imposed by $\$ 901$ of Title IX. Section 907 (c) (3) excepts "service performed as an officer or member of the crew of a vessel on the navigable waters of the United States."

${ }^{25}$ For a discussion of these problems, see Lotwin, Coverage of State Unemployment Compensation Laws (Jan. I936) 3 Law and Contemporary Problems, 7, 8-i I.

${ }^{10}$ For a discussion of these problems, sec Lotwin, supra note I5, at II-I9.

${ }^{17}$ Social Security Act, Tit. II, \$2Io (b), Tit. VIII, $\$ 8 \mathrm{II}$ (b). 
hard cases which such coverage may produce will be avoided by the simple device of tax evasion.

\section{The Benefit Payments}

\section{(a) The Old-Age Annuity}

.Monthly benefit payments begin on January $\mathrm{r}$, 1942, to those persons who are "qualified individuals" under the definition indicated above. ${ }^{18}$ A qualification to that definition must, however, be noted. To avoid the necessity for making countless small payments, only those individuals are regarded as qualified whose total wages (a term which is here and will hereafter be used in the statutory sense) amount to $\$ 2,000 .^{19}$ Persons attaining the age of 65 without having earned this sum after 1936 or without having been employed in occupations covered by the Act at least one day in each of five calendar years after 1936 are entitled to receive a lump sum payment equal to $3 \frac{1}{2} \%$ of their total wages. ${ }^{20}$ Claims for these payments will doubtless begin to be made shortly after January I, 1937 , by persons attaining age 65 . Those whose claims mature early will receive more than the value of what they will have paid in taxes, but the sums thus distributed will not be large.

The amount of the monthly benefit payments is stated in terms of a percentage of the total wages received since December I, 1936. The statutory definition of wages covers "all remuneration of employment" including "the cash value of all remuneration paid in any medium other than cash" up to $\$ 3,000$ paid by any one employer with respect to employment during any calendar year. ${ }^{21}$ For the purposes of calculating benefit payments (and, of course, tax payments as well) so much of a person's wages as exceeds $\$ 3,000$ in any given year will be disregarded-except in the occasional case where the total wages received from two or more employers in one year exceeds that sum.

The percentage rates are graduated so as to afford those who are now close to age 65 and whose wages are low a more substantial benefit in proportion to their tax contribution than the younger and the more highly paid employees. This practice is common among private industrial pension plans, and, as is explained elsewhere in this symposium, to maintain a strict relationship between tax payments and benefits would result in absurdly low benefits to those now favored by the graduated scheme. ${ }^{22}$ The percentage rates established for benefit payments are as follows: ${ }^{23}$

On the first $\$ 3,000$ of wages......................... $1 / 2 \%$

On the next $\$ 42,000$ of wages........................

On all wages exceeding $\$ 45,000 \ldots \ldots \ldots \ldots \ldots \ldots \ldots \ldots .1 / 24 \%$

Assuming that a man attaining age 65 on January $1, x 946$, had earned wages of $\$ 3,000$ per year for the nine years subsequent to 1936 . His monthly payment would

\footnotetext{
${ }^{18}$ Id., Tit. II, $\$ 202$ (a).

${ }^{20}$ Id. $\$ 204$ (a).

2 See Brown, supra note 2, at p. 194.

${ }^{23}$ Social Security Act, Tit. II, $\$ 202$ (a).
}

${ }^{10} I d$. \$210 (c) (3).

"Id. 5210 (a). 
be $1 / 2 \%$ of the first $\$ 3,000$, or $\$ 15.00$, plus $1 / 12 \%$ on the remaining $\$ 24,000$, or $\$ 20.00$, making a total monthly benefit of $\$ 35.00$. Obviously, this annual income of $\$ 420$ would require either a marked readjustment in his living standards or resort to other sources of income. If, however, he were to continue in regular employment after attaining age 65 , he would be denied a benefit for each month in which he worked thereafter, ${ }^{24}$ although his wages for such work would not continue subject to tax.

The application of the percentage scale calls for no more than a simple exercise in arithmetic; the table in the footnote presents some representative results. ${ }^{25}$ It should, however, be emphasized that the benefit rate is low and will be especially low for a number of years to come. The requirement of a minimum of $\$ 2,000$ in total wages to qualify persons for monthly benefits results in a minimum benefit rate of \$io per month. The limitation of wages to $\$ 3,000$ earned in any one year places a maximum ori benefit payments which will, of course, increase slightly with each successive year. But by 1957 the largest possible benefit payment ${ }^{25^{2}}$ payable would be $\$ 56.25$ per month and a man who had averaged $\$ 1,500$ per year throughout the 20-year period would receive but $\$ 37.5^{\circ}$ per month. The Act, moreover, sets a maximum of $\$ 85.00$ per month for benefit payments. ${ }^{28}$ However, a man who had received not less than $\$ 3,000$ per year for 45 years subsequent to December 3I, I936 and prior to attaining age 65, would lose but $\$ 2.50$ per month by reason of this limitation.

\section{(b) Payments upon Death}

In two situations under the Federal Act, death benefits are payable: first, where a person dies prior to attaining age 65 but after having engaged in employment subject to the Act, and, second, where a person who is in receipt of benefits dies before the total benefit payments received are equal to $3 \frac{1}{2} \%$ of his total wages since 1936 . The Act provides, in the former situation, that the estate of the decedent shall be paid $3 \frac{1}{2} \%$ of such total wages, ${ }^{27}$ and, in the latter, that his estate shall receive the amount by which the benefits actually paid to him was less than that percentage. ${ }^{28}$

These two provisions thus operate to insure to employees subject to the Act a minimum return of at least $3 \frac{1}{2} \%$ of the wages on which they have paid a tax which, beginning at $\mathrm{x} \%$, increases, as will be seen, ${ }^{29}$ over a period of years to $3 \%$. Those who die before the tax reaches the $3 \%$ rate or who die thereafter, having paid a lower

2 Id. $\$_{202}$ (d).

${ }^{2}$ The following table is taken from the Report of the Senate Finance Committee on the Social Security Bill, Sen.'Rep. No. 628, 74th Cong., Ist Sess. (1935) 8.

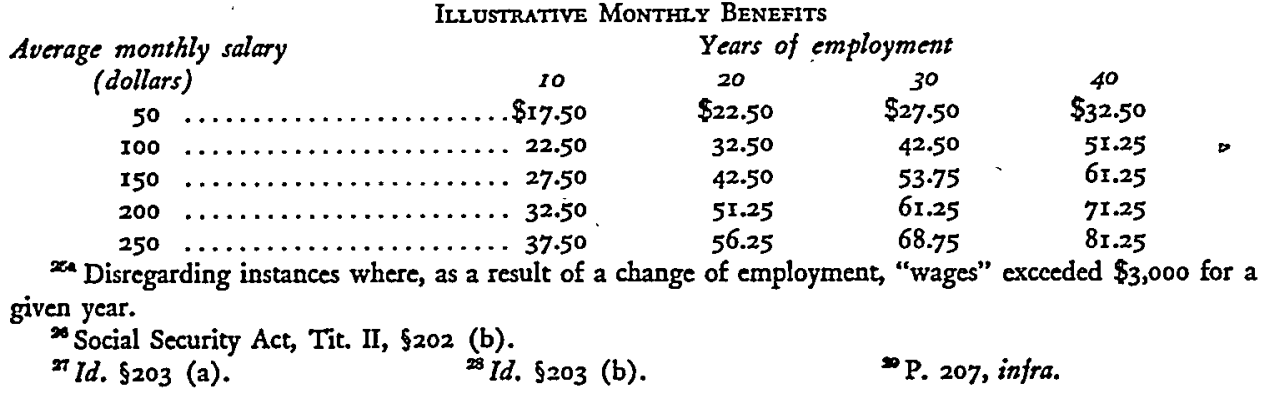


tax rate on the greater portion of their total wages, will receive somewhat more in death benefits than they will have paid in taxes. The estates of those decedents entering employment after the $3 \%$ rate has been reached will probably not receive complete reimbursement since the $1 / 2 \%$ by which the death benefit exceeds the tax rate will not long serve to balance the interest accumulating on the tax contributions. $^{30}$

Although for a number of years the death benefits (which are not deferred until I942, as are the old-age benefits) will be negligible in amount, they will in time reach significant proportions, even for the small wage-earner. Thus a man who dies after having earned $\$ 1,000$ per year for to years subsequent to 1936 will have secured for his estate the sum of $\$ 350$. The importance of this sum will be more readily appreciated when it is realized that the average face value of the eighty-one million industrial life insurance policies outstanding in 1933 was little over \$210 and the average amount of insurance carried per insured was only about $\$ 3000^{81}$

The amount of the death benefits is not likely to reach proportions sufficiently large to affect adversely the sales of ordinary life insurance. Although no statutory maximum is specified, the $\$ 3,000$ limitation on annual wages will operate to make it virtually impossible for death benefits ever to exceed $\$ 5,000$ even after the system has been in operation $5^{0}$ years. The average death benefit will, of course, be much lower.

\section{(c) Administration of Benefit Claims}

The Act does not attempt to specify the machinery through which benefit payments are to be administered beyond vesting the power to determine the amounts. payable in the Social Security Board. ${ }^{32}$ The Board, however, is accorded power to make such rules and regulations, not inconsistent with the Act, as may be necessary to its efficient administration. ${ }^{33}$ It is through the exercise of this rule-making power that the administrative structure of the system will be created. And, although this is still in its preliminary stages, a few of the administrative problems may be anticipated.

The requirement that benefit payments be based on total wages received after

${ }^{30} \mathrm{~A}$ more precise form of relating the death benefit to contributions would have been to repay to the decedent's estate the amount contributed in taxes by the decedent, plus interest at a specified rate on the tax payments. But this method would have been administratively burdensome, and its adoption would have seriously impaired the separation between tax and benefit payments which the Act's draftsmen sought to maintain.

${ }^{21}$ See 1935 Wordd Alasanac 284; Tayzor, The Social Cost of Industrial Life Insurance (1933) 53-54. The effect of the death benefits of the federal system upon industrial insurance is hard to predict. It will not take many years of employment to accumulate benefit rights equal to those now obtained in industrial insurance. Since unemployment or a change in employment to an excepted occupation does not abrogate claims based on prior employment in occupations subject to the Act, the risk of lapse, so great in industrial insurance, is eliminated. The whole system can, it is true, be terminated or modified by Congress, but legislation reducing the claims of beneficiaries approaches the politically unthinkable. Possibly the stimulus given by the Social Security Act to interest in the insurance principle may redound to the benefit of the industrial insurance companies.

${ }^{*}$ Social Security.Act, Tit. II, \$\$202-207, 2I0 (c). $\quad{ }^{\infty}$ Id., Tit. XI, \$1102. 
December 3r, I936 requires the establishment of a tremendous system of records covering the employment record of, to begin with, about 25 million employees. ${ }^{34}$ Since, however, the taxes levied by Title VIII are also based on the same wages it is evident that the machinery for the collection of taxes can be utilized to obtain the data necessary for the payment of benefits. This problem will be dealt with herein in connection with the tax collection problem.

The Act directs the Board to certify the names and addresses of applicants for benefits and the amount of the payments to which they are entitled to the Secretary of the Treasury who, "through the Division of Disbursement of the Treasury Department, and prior to audit or settlement by the General Accounting Office, shall make payment in accordance with the certification by the Board."35 Certification by the Board does not, however, preclude it from making adjustments if it is later found that a beneficiary was entitled to a greater or less sum than that certified. Provision is made for these adjustments to be effected in connection with subsequent payments to him. ${ }^{36}$ Where, however, the beneficiary has died before the ascertain- . ment of the error in the certification, the amount of any underpayment will be paid to his estate and his estate will be liable for any overpayment. ${ }^{37}$

No doubt administrative machinery will be established for the determination of contested claims. But will rulings by the Board with respect thereto be subject to judicial review? The Act makes no provision for recourse to the courts by an aggrieved claimant, yet it does not expressly limit the claimant solely to an administrative remedy. ${ }^{38} \mathrm{~A}$ very recent decision of the Supreme Court, ${ }^{38}$ interpreting the Civil Service Retirement Act, holds that the claim of a government employee to an annuity thereunder is a claim "founded upon a law of Congress" within the meaning of the statutes authorizing suits against the United States. Although that act provides an administrative remedy the Court ruled that "in the absence" of compelling language resort to the courts to assert a right which the statute creates will be deemed curtailed only so far as authority to decide is given to the administrative officer." $39^{*}$ "The Retirement Act grants (as does Title II of the Social Security Act) ${ }^{40}$ power to the administrative official to determine the questions of fact upon which the claims for annuities are based, but this was not held to preclude judicial review in a suit upon the claim in the District Court when the administrative determination is "arbitrary or capricious or unsupported by evidence," when the procedure followed fails to

See Richter, The Actuarial Basis of the Cost Estimates of Federdi Old-Age Insurance, infra, at p. 215.

${ }^{2}$ Social Security Act, Tit. II, \$207.

${ }^{50}$ Id. $\$ 202$ (c).

${ }^{3} I d . \$ \$ 203$ (c), 206 .

"Such a limitation would be constitutional. Lynch v. U. S., 292 U. S. 571,582 (1934).

${ }^{*}$ Dismuke v. U. S., 56 Sup. Ct. 400 (I936). ${ }^{302}$ Id. at 403.

"All references to amounts on which payments to beneficiaries are based are stated in terms of amounts "the Board finds" or amounts "determined by the Board." See Social Security Act, Tit. II, \$\$202-206. "Qualified individuals" entitled to receive benefit payments are persons "with respect to whom it appears to the satisfaction of the Board" that the specified requirements have been met. Id. 5210 (c). The language is apt for the grant of discretionary power, beyond reach of the writ of mandamus. 
satisfy "elementary standards of fairness and reasonableness," or when, the facts having been conceded, the question becomes one as to the applicability of the law. ${ }^{41}$ There is little in the language either of the two statutes or of the Court's opinion to suggest that a different result would be reached with respect to claims arising under Title II. ${ }^{41^{a}}$ It seems apparent, therefore, that a wide field for judicial review will remain open unless and until Congress sees fit to deny to beneficiaries all recourse to the courts.

It seems safe to predict that whatever machinery may be created by the Social Security Board for the hearing of claims of aggrieved beneficiaries, it will suffer from no lack of business, especially after claims begin to attain dimensions sufficiently large to nourish litigation. Doubtless, it will be found essential to make provisions for the hearing of claims (and, more important still, for the adjustment of errors in records long before the right to benefits accrues) in local offices throughout the country, with provision for review in regional offices or in Washington. The business of representing claimants is likely to prove inviting to the shyster and the runner, and regulations restricting the right to represent claimants-and also the compensation of the representatives-will probably become necessary. ${ }^{42}$

The Act protects benefit payments from the improvidence of the beneficiaries by declaring the right to further payments non-assignable at law or in equity and "none of the moneys paid or payable or rights existing under this title shall be subject to execution, levy, attachment, garnishment, or other legal process, or to the operation of any bankruptcy or insolvency law."43 .There is some question, however, whether, when payment of a death benefit is made to the beneficiary's estate, the proceeds will not be liable to be applied in satisfaction of the debts of the decedent. ${ }^{44}$

As a sanction against misrepresentation by applicants, one making "any false state-

a Dismuke v. U. S., 56 Sup. Ct. at 403 .

112 The Court, id. at 402, points out that the Retirement Act provides that the employec "shall be entitled to an annuity." The Social Security Act, $\$ 202$ (a), provides that "every qualified individual ... shall be entitled to receive . . . an old-age benefit." However, the Court observes further: "The provision is mandatory, expresed in terms of the right of the employee, which is inseparable from the correlative obligation of the employer, the United States." (Italics added.) I doubt, however, that the Court's reference to the United States as "the employer" has greater significance than a descriptio personae. The "obligation" referred to seems that arising from the statute, regardless of whether the retirement annuity system is regarded as contractual in character. Hence, even though a beneficiary's claim to an old-age benefit is not founded on contract, so long as the statute stands, he would have a right to the bencfit, and the government would be subject to a correlative obligation.

'Such restrictions are embodied in many workmen's compensation and some unemployment compensation acts. They are briefly discussed in Dodd, Administering Unemployment Compensation Benefit Claims (Jan. 1936) 3 Law and Contemporary Problems, 107, I12-113.

"Social Security Act, Tit. II, \$208.

"Special provision is made for the payment of death benefits of less than $\$ 500$. The Board is authorized to prescribe regulations for the payment of such benefits to the persons found by it "to be entitled thereto under the law of the State in which the deceased was domiciled, without the necessity of compliance with the requirements of law with respect to the administration of such estate." Id. \$205. It seems evident that such direct disbursements to the next-of-kin of beneficiaries would not be subject to the claims of their, or the decedents', creditors. 
ment as to any material fact, knowing such statement to be false" is subject to a fine not to exceed $\$ 1,000$ or imprisonment for not more than one year, or both. ${ }^{45}$

\section{The Tax Provisions of Title VIII}

As has already been indicated, Title VIII levies two taxes, an income tax on employees $^{46}$ and an excise tax on employers. ${ }^{47}$ Both taxes have the same baseswages paid in employment not excepted from the Act, not exceeding $\$ 3,000$ paid to any one person by any one employer.in any calendar year. The rates for both taxes are also identical. These are indicated in the table following:

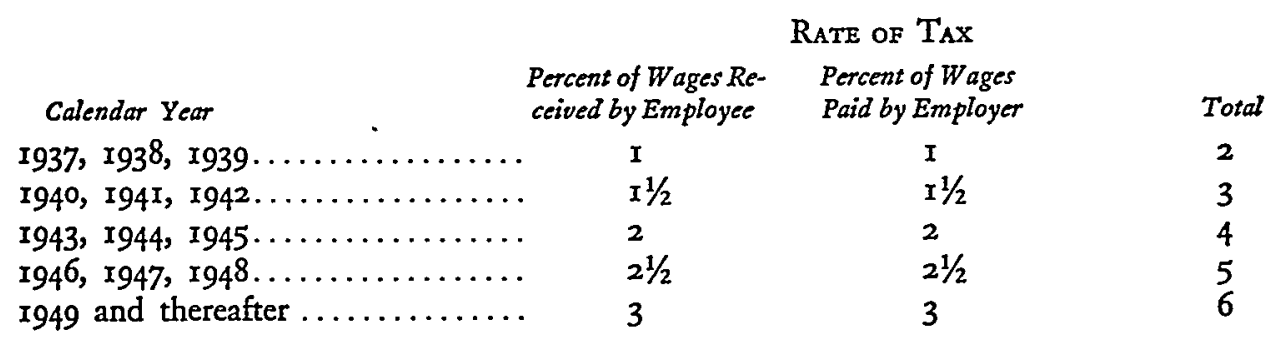

The income tax levied on employees' wages is to be collected by their employers who are made liable therefor and who must deduct it from the wages as and when paid. ${ }^{48}$ The income tax is not deductible by the taxed employee in computing his net income for purposes of the regular income tax. ${ }^{49}$

The Bureau of Internal Revenue is charged with the collection of both taxes, the proceeds of which are paid to the Treasury as internal-revenue. collections. ${ }^{50}$ The Commissioner, with the approval of the Secretary of the Treasury, is authorized to make rules and regulations for the enforcement of the title. ${ }^{51}$ This rule-making power extends to the determination of the time and conditions of paying the tax, a responsibility which presents perhaps the most difficult administrative problem posed by the entire Act.

\section{Tax Collection Procedure}

If the task of the Bureau of Internal Revenue were merely to insure the payment of the taxes levied by Title.VIII, the job would be formidable enough but not nearly so herculean as that which an interlinear reading of the statute indicates it is expected to perform. The tax collection machinery, if a tremendous duplication of effort is to be avoided, must be so constructed as to provide a record of the wages received by taxed employees which can be used by the Social Security Board in determining the

4 Id. $\$ 209$.

"Id., Tit. VIII, \$801.

${ }^{20} I d$. $\$ 802$ (a). The employer is indemnified by this section against "claims and demands of any person for the amount of the" tax deducted.

1 Id. $\$ 803$.

${ }^{50} 1 d . \$ 807$ (a).

2 Id. $\$ 807$ (b). Paragraph (c) of this section renders applicable to the Title VIII taxes "all provisions of law including penalties, applicable with respect to any tax imposed by section 600 or section 800 of the Revenue Act of 1926, and the provisions of section 607 of the Revenue Act of 1934 . . insofar as applicable and not inconsistent with the provisions of this title." 
amount of benefits payable to them. Nowhere in Title VIII is this obligation placed upon the Bureau of Internal Revenue, but, fortunately for the scheme of separating the tax and benefit systems, the business of acquiring the data essential to the discharge of the Board's duties will not compel the Bureau to impose regulations which are foreign to its tax collecting function, even though regulations may be promulgated which but for this ulterior objective might otherwise be dispensed with.

For both the tax collection and benefit record purposes, it is obviously desirable that there be employed a means of identifying the taxpayer more precise than merely recording his name and address. In the not distant future, therefore, it is probable that every person in employment subject to the Act will be registered and a serial account number assigned to him, which will be used by both the Bureau and the Board. The registration process will not require the eliciting of much data concerning the registrant, but it will afford an opportunity to ascertain his age, a vital fact for the Board's records. ${ }^{62}$ Upon the completion of the registration process, the Board will have a substantially complete record of the names and ages of all persons then within the system. Provision will doubtless be made for the registration of newcomers at the time they enter employment in occupations subject to the Act.

Since the employee's benefit payment rights are dependent on an accurate record of his wages being maintained by the Social Security Board and since it will derive its information from the fact of tax payments made on his behalf by his employer, it is important that the employee himself obtain a record of such tax payments so that he will have some evidence of his right to benefit payments. This consideration, together with the desirability of furnishing a simple mechanism for use by the small employer, suggested the possibility of utilizing a stamp book or card system of tax collection similar to that employed in some social insurance systems abroad. In such a system a card is issued to each registrant on which squares are ruled off and dated for each week in, say, the six months' period for which the card is issued. The employer purchases a stamp of a denomination equal to the total of his and his employee's taxes for a single week and attaches that stamp to the appropriate place on the card, thus indicating that the tax has been paid. At the end of the period, the employee turns the card in to the insurance authority and a new card is issued to him. The stamped cards, filed with the authority, constitute a record on which it may pay benefits to the insured. ${ }^{58}$

Provision for the adoption of some such scheme was made in Title VIII, the Commissioner of Internal Revenue being authorized to furnish to the Postmaster General stamps, coupon books, etc., to be sold by the Post Office Department to

\footnotetext{
The significance of age is, of course, of less consequence than in life insurance where it determines the size of the premium. An overstatement of age will hasten the commencement of benefits, but it will diminish their amount, and the converse is true. Probably overstatements and understatements of age will tend to cancel out.

* For a brief description of the stamp card plan, accompanied by a facsimile of a card used in the British National Health Insurance System, see Statemeat of $J$. Douglas Brown, Hearings before the House Ways and Means Committee on H. R. 4120 (Economic Security Aict) 74th Cong. Ist Sess. (1935) 246-247.
} 
employers. ${ }^{54}$ I am informed, however, that there is little likelihood of the adoption of the stamp system of tax collection for the Old-Age Insurance System. Among the principal objections to it seem to be the following: (I) In the systems where it is used abroad (and its use has been discontinued in several countries) all tax payments are for the same amount. Here, however, where tax payments are a percentage of wages, their amounts will vary with the wages from person to person and from week to week. Thus, the two taxes with respect to an hypothetical employee may run $\$ 1.22$ one week, $\$ 0.98$ the next, and \$1.36 the week following. Obviously the business of supplying stamps in the denominations necessary to meet such variations would be a difficult task both for the government and for the employer, however alluring a prospect it might open up for the philatelist. (2) The stamp cards would not constitute reliable evidence on which to base benefit payments. Suppose father and son are both employed in occupations subject to the Act, but father, in his late fifties, earns less than his son. If son's stamps were placed in father's book, the latter's benefits, soon to be realized, would be augmented considerably. Despite criminal penalties, ${ }^{65}$ stamp trading sessions around the family teakettle would be quite predictable. A traffic in stamps outside the family circle might also develop between young Esaus and elderly Jacobs. (3) For the large employer the handling of weekly stamp entries would be inconvenient unless satisfactory stamp meters were devised.

It is highly probable that instead of the stamp device the more orthodox method of the tax return filed by the employer will be resorted to. No information is as yet available as to the frequency with which such returns will have to be made. A prediction may be hazarded, however. Tax payments will be required to be made at relatively frequent intervals, perhaps monthly, but the returns for these will show only the total payroll and the total tax payable. Less frequently, returns will be required to show the break-down of that payroll among the individuals comprising it. This differentiation will at once insure a steady flow of tax payments and minimize the administrative burden of handling individual returns.

The problem of the form to be taken by the return indicating individual tax payments remains, so far as information is available, an unsolved problem. Illustrative of the nature of this problem and of the difficulties inherent in it are some suggestions which have been proffered for meeting them. One ingenious device calls for the use of attached duplicate cards for each employee, one of which is to be given to the employee and the other returned to the Bureau. Each card sets forth the name, address, account number, and wage record of the employee, and on the margin common to the two cards there is printed on both sides a series, in columns, of amounts ranging, say, from $\$ 10$ to $\$ 500$. The attached cards are to be separated in such manner as to divide the column containing the amount in this series closest to the total wages received by the employee during the period covered by the return at the point where that figure appears. If later the employer seeks to alter the written

st Social Security Act, Tit. VIII, $\$ 809$.

$\$$ Id. $\$ 8 \mathrm{ro}$. 
entry on the card showing the amount paid in order to reduce his tax, the lowered amount will not correspond to the figure at the point of separation. If the employee seeks to increase the entry on his card, a similar discrepancy will appear.

This device must face the objection that it or any system which obliges the employer to write in the employee's account number on the return will cause difficulty. The numbers inevitably will be long and the likelihood of clerical error considerable. Since the elaborate mechanical recording devices which the Board must employ will have to be organized numerically, the cost attributable to errors in account numbers will be serious.

A possible solution to this difficulty may be the issuance to each registrant of a metal plate, resembling in some respects an addressograph plate, which will bear his name and account number. This could be so designed as to fit into the payroll machines of the large employers or into a simple holder for use by small employers. Loss of the plate would, of course, create difficulties, but foreknowledge of these difficulties would foster care on the part of the owner.

Another method which has been suggested for assuring accurate records of individual wage-earnings is for the Social Security Board to prepare and send to each employer a return in duplicate listing all the employees with their account numbers whom the employer had listed in his preceding return. The employer would then enter the wages paid and the amount of the tax payable for each employee on this list who had remained in his employ, indicating those instances where employment had terminated and making appropriate additions for new employees. The duplicate of this return would be divisible into individual slips which would be given by the employer -or by the Board itself-to his employees to inform them of the tax payment. The burden imposed on the Board in preparing these returns would not be considerable, the employer would be aided, and the risk of clerical error diminished.

Neither this procedure nor that previously suggested anticipates reliance on the duplicate returns received by the employee to establish his claim, although they may serve as a check against error and against tax evasion by the employer. Where employee and employer collude to return wages at an amount lower than that actually paid, of course, none of the systems will afford protection. Self-interest on the part of most employees will be a safeguard against this, and the gains of tax evasion will not be so great as to tempt many employers to resort to it. ${ }^{.68}$ There is, of course, the usual safeguard of administrative surveillance, fortified by criminal penalties for false returns.

Where evasion will probably be most frequent will be in the employment of casual labor. Casual labor is excepted from the operation of the Act only if it is "not in the course of the employer's trade or business."

${ }^{50}$ What an employer gained on his payroll tax, he might lose on his income tax, since payrolls are deductible from income. Moreover, experience under the latter tax does not indicate much attempt at tax evasion by payroll padding.

${ }^{G} I d .$, Tit. II, \$210 (b) (3), Tit. VIII, \$8II (b) (3). 
businesses require casual labor frequently. A caterer, for example, does not maintain a large staff of waiters on his payroll ready for the emergency of a banquet. When his need arises, he sends forth a call which is responded to by those waiters of the vicinage who may be "at liberty." They do their stint and receive their stipend, often without being troubled to disclose their names. It is no easy task to devise a satisfactory method of tax collection and wage recording which will be effective and yet not unduly hamper the functioning of such informal methods of employment as this. Indeed, as one considers the diversity of occupations covered by the Act, it is difficult to suppose that any single method can be devised which will satisfactorily meet all situations. It seems safe to predict that ultimately, if not initially, a variety of procedures will be devised and adapted to varying types of employment.

However fragmentary may be the information as yet available with referençe to the administrative set-up for the collection of the old-age insurance taxes, it is clearly evident that simplification of the employer's accounting burden is an objective which is being kept to the forefront and that those accounting systems offered to employers by commercial publishers soon after the passage of the Social Security Act, which called for a detailed inquiry into the life history and status of each employee, will prove wholly unnecessary. 